\title{
МЕДІАТЕКСТ ЯК ІНСТРУМЕНТ У НАВЧАННІ УКРАЇНСЬКОЇ МОВИ ЯК ІНОЗЕМНОЇ
}

\author{
НАТАЛІЯ СКИБА \\ Київський національний університет імені Тараса Шевченка, Київ - Україна \\ TEKST MEDIALNY JAKO NARZĘDZIE \\ W NAUCZANIU JĘZYKA UKRAIŃSKIEGO JAKO OBCEGO
}

\author{
NATALIA SKYBA
}

Kijowski Uniwersytet Narodowy im. Tarasa Szewczenki, Kijów — Ukraina

STRESZCZENIE. Jednym z trendów w optymalizacji nauczania języków obcych ukierunkowanych zawodowo jest wykorzystanie technologii informacyjnych i komunikacyjnych, jakie proponują włączenie do procesu nauczania obcojęzycznych tekstów medialnych różnego rodzaju (artykuł w gazecie, program w TV, film, internet). Tekst medialny jest autentycznym źródłem informacji o charakterze lingwistycznym, społeczno-kulturalnym, krajoznawczym.

\author{
USING MEDIA TEXTS AS THE INSTRUMENT \\ IN TEACHING UKRAINIAN AS A FOREIGN LANGUAGE \\ NATALIIA SKYBA \\ Taras Shevchenko Kyiv National University, Kyiv - Ukraine
}

ABSTRACT. The mass media and the linguistic means used to mediate information constitute an important resource for persons studying a language as foreign one. Media texts give students a possibility to get acquainted with contemporary lexical, grammatical and stylistic changes. In addition, through the media language and its structure the reader obtains information - quite often implicit information — about the society, its history and culture.

$\mathrm{Y}$

сучасному суспільстві дедалі зростає роль засобів масової інформації та комунікації (телебачення, мультимедійні комп'ютерні системи, Інтернет, друковані 3MI, кіно), без використання яких вже не можна уявити собі життя й освіту. В умовах інформаційного суспільства, що вимагає від фахівців з іноземної мови не тільки високої кваліфікації, але й уміння критично й творчо мислити, вдосконалюватися й адаптуватися до швидкозмінних потреб соціуму, перед викладачем іноземної мови стоїть комплекс завдань. Необхідно навчити студента орієнтуватися в інформаційному просторі: вміти знаходити й передавати важливу інформацію, аналізувати іiі, відокремлювати істинне від неправдивого. Зважаючи на вищесказане, актуальним компонентом сучасної освіти стає медіаосвіта.

На думку О. Федорова, „медіаосвіта - це процес розвитку особистості за допомогою й на матеріалі засобів масової комунікації (медіа) з метою формування культури спілкування з медіа, творчих і комунікативних здібностей, критичного мислення, вміння повноцінного сприйняття, інтерпретації, аналізу й оцінки медіатекстів, навчання різноманітних форм самовираження за до- 
помогою медіатехніки" Під медіатекстом розуміємо повідомлення, передане у відповідному вигляді й жанрі медіа, зокрема газетна стаття, телепередача, відеокліп, фільм тощо.

3MI, їхній зміст і способи передачі інформації є гарним джерелом для того, хто вивчає іноземну мову. Медіатексти — це аутентичні джерела актуальної інформації лінгвістичного, соціокультурного, лінгвокраїнознавчого і т. п. характеру. За допомогою медіатексту можна ознайомитися 3 новітніми лексикостилістичними змінами мови, а також із сучасними тенденціями іiі розвитку. Крім того, через мовну структуру студент дізнається багато цікавої та корисної імпліцитної інформації про суспільство, мову якого він вивчає. Зауважимо, що в мові ЗМІ простежуємо й лексико-граматичні, й стилістичні зміни, що їх репрезентує новітній український медіатекст, можна спостерігати, наскільки мова мас-медіа співвідноситься з літературною нормою, бачити культурологічний контекст, у якому українські медіатексти власне й створюються. Саме цей суспільно-культурний контекст викликає найбільші труднощі в студентів. Незнання культури, побуту України, зокрема іiі радянського періоду, нерозуміння прецедентних феноменів часто ускладнюють сприйняття й тлумачення змісту медіатексту.

Питанням медіаосвіти присвячені праці багатьох дослідників, зокрема Н. Чичериної ${ }^{2}$, О. Федорова ${ }^{3}$, Ф. Аблякімової ${ }^{4}$, Т. Добросклонської усі вони пропонують методику подачі медіатексту під час вивчення іноземної мови, зокрема англійської.

Використання конкретних типів і видів медіатекстів як засобу формування медіакомпетенції студентів потребує вивчення форм і методів роботи з ними. Відзначити інтерактивні форми й методи, що поділяються на дискусійні (діалог, групові й колективні дискусії, обговорення "витворів" медіакультури, аналіз ситуацій), ігрові (літературно-імітаційні, театралізовано-ситуативні і под.; завдання, що грунтуються на медіаматеріалі), тренінгові, що поєднують дискусійні та ігрові форми роботи на медіаматеріалі. Працюючи зі студентами, рівень знань яких окреслюється як "початковий”, викладач може сформулювати завдання на виявлення відмінностей між медіатекстами, в яких викладаються факти, й між медіатекстами, в яких висловлюється суб'єктивна думка. Ще однією формою аналізу може бути критичний розгляд заголовків 3МI, що відображають один і той самий факт або подію, явище.

На "просунутих" етапах навчання мови студенти можуть аналізувати авторські статті на задану тематику, листи читачів до редакції тощо. Після закінчення аналізу можна підготувати презентації в Power Point, у яких відтворені соціальні, культурологічні й лінгвістичні характеристики авторів. Акцент на проблемних, евристичних, ігрових та ін. продуктивних формах навчання сприяє формуванню самостійного творчого мислення. Можливі завдання: прочитайте статтю, знайдіть аргументи "за" й "проти"; розгляньте позитивні й нега-

${ }^{1}$ А. В. Фед оров, Словарь терминов по медиаобразованию, медиапедагогике, медиаграмотности, медиакомпетентности, Таганрог 2010, с. 25.

${ }^{2}$ Н. В. Ч и че р и н а, Концеепция формирования медиаграмотности у студентов языковых факультетов на основе иноязычных медиатекстов, СПб. 2008.

${ }^{3}$ А. В. Фед оров, указ. источник.

${ }^{4}$ Ф. Г. Аб л я к и м в а, Иноязычный медиатекст как средство формирования медиакомпетентности будущих учителей английского языка, [в:] Электронный ресурс: http://www.nbuv. gov.ua/htm (13.06.2013).

5 Т. Г. Добросклонская, Медиалингвистика: системный подход к изучению языка СМИ: современная английская медиаречь, Москва 2008, с. 264. 
тивні боки ситуації, обговоріть у групах, як можна вирішити цю проблему; поділіться своїми рішеннями проблеми, оцініть чужі рішення. Для творчого розвитку: напишіть есе з иієї теми, подайте свої аргументи, висновки, можливі рімення проблеми, свої думки. У медіаосвітній практиці прийнято ставити проблемні запитання, що не мають однозначної відповіді, напр.: Дайте два пояснення, чому...? Поясніть, чому...? У чому відмінність...? Уявімо, якщо... тощо.

Пропонуємо зупинитися на одному з найскладніших, на нашу думку, аспектів у навчанні мові ЗМІ - аналізі особливостей функціонування на сторінках мас-медіа фразеологічних одиниць, що створюють певні труднощі в адекватному й повноцінному розумінні текстів, у процесі опрацювання яких в іншомовній аудиторії спочатку треба з'ясувати семантику, сформувати цілісне сприйняття тієї чи тієї ФО, відзначити стилістичну роль, що її відіграє ФО в тексті, та "вловити" прагматичну частину їі семантики. Для посилення волюнтативної функції в мові мас-медіа фразеологізми часто підлягають "оновленню", що приводить до формування оказіональної фразеології, яку іноземцеві складно пояснити. 3 іншого боку, мова ЗМІ є демонстрацією мобільності фразеологічного матеріалу ${ }^{6}$. Процес трансформування ФО (процес авторського варіювання ФО, "модернізації", "оновлення" ФО, оказіоналізації) відбувається внаслідок індивідуальної мовотворчої практики, художньо-естетичного новаторства. Використовуючи модель узуальної ФО, автор органічно вводить оказіоналізм у контекст з певною стилістичною, експресивною метою, з метою уникнення одноманітності та прагненням зробити вислів більш містким, образним. Якщо виразова сила мовного елемента збільшується в мовленні за допомогою різноманітних способів і прийомів (модифікація узуальної форми, градація, подвійна актуалізація, субституція, контамінація), то, відповідно, й виникає "мовленнєва комбінована експресивність" (В. Чабаненко) або "подвійна експресивність" (В. Мокієнко). Йдеться насамперед про фразеологізми, що в медіа "обростають" особистим баченням комунікатора, зазнаючи структурносемантичних модифікацій.

У медійних текстах спостерігаємо такі трансформації: 1) семантичні трансформації ФО: а) власне семантичні; б) подвійна актуалізація ФО (буквалізація); 2) структурно-семантичні трансформації ФО: а) якісні зміни або лексична субституція компонентів ФО; б) кількісні зміни, пов'язані з розширенням (нарощення / поширення фразеологізму) та звуженням (усічення або еліпсис та фразеологічний натяк або компресія ФО) традиційних меж ФО; в) комбіновані зміни або контамінація фразеологізмів.

Найпродуктивнішим видом трансформацій є структурно-семантичні, що приводять до зміни денотативно-сигніфікативного та стилістичного аспекту значення ФО, що відбувається одночасно зі зміною зовнішньої форми фразеологізмів. Поява оказіональної одиниці розрахована на адекватне сприйняття iii реципієнтом і завжди асоціюється з традиційним (узуальним) фразеологізмом. Оскільки іноземець позбавлений таких асоціацій, слід віднайти первинний фразеологізм, пояснити його значення, мотивувати трансформації. Такі одиниці хоча й мають індивідуально-суб'єктивний характер, зумовлені системою мови й обмежені можливостями їхнього матеріального оформлення. У процесі викладання української мови в іноземній аудиторії слід це враховувати й наголошувати на "одноразовості" цього стилістичного прийому. Актуальними $\epsilon$ ці знання під час поглибленого вивчення мови студентами-філологами в розділі стилістики.

${ }^{6}$ В . Г. Ко с то ма ро в, Языковой вкус эпохи, Санкт-Петербург 1999, с. 10. 
Найтиповішим способом структурно-семантичних трансформацій ФО $\epsilon$ лексична субституція - заміна компонента. Загальне значення ФО при цьому залишається незмінним, але набуває додаткової експресивності, “образності другого ступеня"7, що відбувається внаслідок зміни внутрішньої форми.

Субституюються здебільшого синонімічні одиниці або одиниці одного порядку; відбувається заміна одного, двох або всіх компонентів ФО (у цьому разі можна розмірковувати про актуалізацію фразеологічної моделі), напр.: Сnpaва складна: захищати підозрюваного чи, навпаки, навісити на нього усіх слонів, порівн.: навісити усіх собак - "звинуватити"8. У подібних контекстуальних ФО іронічність та посилена експресивність вислову досягається зміною інтенсивності - слон, кінь є більшими за собаку та кота; Лишається тупиювати біля ї̈ підніжжя і гризти з досади лікті, порівн.: кусати лікті.

Надзвичайно продуктивним щодо трансформацій у медійних текстах є фразеологізм (пролетіти) як фанера над Парижем - „не реалізувати своїх задумів, невдало щось зробити”, „зазнати невдачі”, що припав до смаку журналістам своєю підвищеною експресивністю: Пролетів, немов фанера над Канном; ... один із кандидатів у мери Запоріжжя, дізнавщись, що пролетів на виборах, як зграя напильників...

Біблійний фразеологізм повернення блудного сина актуалізується в різних контекстах: Повернення блудного депутата, Повернення блудної опозищіï. Наведені приклади свідчать про яскраве стилістичне забарвлення субституйованих ФО: субституція надає фразеологізмові більшої конкретності у зв'язку із зображуваною ситуацією; увиразнює, посилює традиційне значення $Ф О$, вносить у семантику фразеологізмів контекстуальний колорит та створює гумористичний ефект. Вибір більш емоційно забарвленої лексичної одиниці в оказіональній ФО порівняно з узуальним фразеологізмом дає змогу вказувати на зміну інтенсивності та більшої експресивності усього вислову.

Модифікуючи фразеологізм, автор знову повертається до того вільного словосполучення, на основі переосмислення якого й утворився фразеологізм. Перенесення фразеологізму з одного семантичного плану в інший $є$ необхідною умовою субституції.

В. Мокієнко вводить поняття структурної моделі - каркасу ФО, що забезпечує її стійкість і відтворюваність, регулює ï семантичну тотожність.

Треба відзначити й роль внутрішньої форми ФО під час трансформаційних процесів: іiі сутність полягає в тому, що образ ситуації, що лежить в основі фразеологізму, має властивість асоціюватися з іншими ситуаціями як основою для метафоричного переосмислення, тобто детермінує появу нових фразеологізмів, на чому й базуються стилістичні прийоми: Час - нафта, Газ - усьому голова.

У сучасному публіцистичному тексті відбувається зниження мовних засобів, створюється нова норма публічної мовленнєвої поведінки, яку можна назвати авторською іронією - авторським кепкуванням та суб'єктивною оцінкою, самоіронією. О. Тараненко називає подібне явище „несерйозною цитацією”, коли цілком серйозні речі подають в абсолютно несерйозному стилістичному ключі, висловлюється іронічне ставлення до канонів, включаючи й най-

7 Л. Ю. Ше в е н ко, Трансформація фразеологічних одиниць у газетному тексті, [в:] Особливості мови і стилю засобів масової інформації, Київ 1983, с. 74.

${ }^{8}$ Усі приклади дібрано з газети "Україна молода" за 2012-13 роки.

${ }^{9}$ О. О. Таран е н ко, Колоквіалізаиія, субстандартизаиія та вульгаризація як характерні явища стилістики сучасної української мови (з кін. 1980 рр), [в:] „Мовознавство”, 2002, № 4-5, c. $37-38$. 
сакраментальніші їхні моменти. Активною в ЗМІ $є$ цитація або квазіцитація та алюзійне цитування, що є атрибутом мовної гри адресата - адресанта тексту, про що свідчить аналіз заголовків та рубрик статей. Поширеним $є$ перетворення висловів, гасел, закликів, цитат та назв ідеологічих творів епохи соціалізму, що набувають іронічного звучання, напр.: Перед Черкасами замерехтів привид нових виборів; Привид Мадрида над Європою, порівн. із висловом „Привид бродить по Європі, привид комунізму" з Маніфесту комуністичної парmiï. Такі цитати подаються переважно без лапок, вони наче "вмонтовуються" в авторський текст. Насамперед "робиться ставка" на широковідомі цитати класиків літератури, крилаті вислови, рядки популярних пісень, кінофільмів, напр.: Ще не змерзла Украӥна; Ну що б, здавалося, кіно...; Тесей був парубок моторний; Лупайте сей паркан! В бій ідуть самі школярі; Наша корупиія - одна з "найкраших" у світі; ФАРС: злочин і кара; Покажси мені свій диплом, і я скажу, хто ти; Хто навпростеиь прямує - у травматології ночує; Банкірів на “переправі” не міняють.

Продуктивними є кількісні зміни, пов'язані з розширенням фразеологізму (або його нарощенням / поширенням). Узуальна ФО набуває в контексті додаткових компонентів та нової образності, порівн.: Як затягують податковий пасок мільйонам трударів Украӥни; Фінанси співають виборам романси; 3 ким у парламенті поведешся, того й наберешся; Американська коса на іракський камінь; Америка підкладає Свропі свиню. І не одну. Ой не дивися, Грищю, телевечорнииі...

Цікавим є прийом контамінації, поєднання двох фразеологізмів, що дає змогу створити новий експресивний образ, напр.: Учітеся „брати мої”, „та не з москалями”; Соломинка чи рятівний круг наиії; Світло у кінці глухого кута тощо. Т. Винокур називає це явище „комунікативним співавторством”10, у якому провідна роль належить мовній грі - розгадуванню, згадуванню. Однак іноземець позбавлений такого "співавторства". Асоціативний простір побутування модифікованих ФО пов'язаний із рівнем їхнього розуміння / нерозуміння, що зумовлює адекватність сприйняття. Подібні ФО та їхні авторські інтерпретації потребують певних фонових знань з боку реципієнта інформації; залежать від рівня освіченості та нагромаджених людиною знань. У цьому разі в іншомовній аудиторії: все це залежить від знань викладача й умінь донести цю інформацію до студента.

${ }^{10}$ Т. Г. В и н о кур, Говорящий и слущающий: Варианты речевого поведения, Москва 1993, c. 84 . 